\title{
Variasi Pola Mencari Makan Tiga Jenis Kuntul di Sekitar Cagar Alam Pulau Dua Serang, Propinsi Banten
}

\author{
Dewi Elfidasari \\ Program Studi Biologi (Bioteknologi), Fakultas Sains dan Teknologi, \\ Universitas Al Azhar Indonesia, Jl. Sisingamangaraja, Jakarta 12110 \\ email: $\underline{\text { d-elfidasari@uai.ac.id }}$
}

\begin{abstract}
Abstrak - Variasi pola mencari makan dari tiga jenis kuntul yang menghuni Cagar Alam Pulau Dua telah diamati selama 12 bulan. Penelitian dilakukan di lokasi makan dari ketiga jenis kuntul yang berada di sekitar kawasan Cagar Alam Pulau Dua. Metode penelitian yang digunakan adalah pengamatan langsung dengan didukung oleh pengambilan gambar menggunakan Handycam dengan metode Focal Observation. Hasil penelitian ini menunjukkan bahwa pola mencari makan pada Casmerodius albus adalah sebanyak 30 pola, variasi pola tertinggi dijumpai pada sawah di waktu pagi (17 pola), dan pola mencari makan yang paling sering dilakukan adalah PCa1. Pola mencari makan Egretta garzetta meliputi 160 variasi tertinggi dijumpai pada lokasi makan dataran lumpur pada waktu pagi (47 macam pola), dan macam pola dengan frekuensi tertinggi adalah PEg1. Sedangkan pada Bubulcus ibis, pola mencari makan yang ditemukan adalah sebanyak 65 jenis, dengan variasi tertinggi dijumpai pada sawah di waktu pagi (33 pola) dan pola mencari makan dengan frekuensi tertinggi adalah PBi15.
\end{abstract}

Abstract - Foraging pattern variation of three herons species living in Pulau Dua Nature reserve Serang, Banten Province was observed to 12 months. Research was conducted done at feeding area of three species of herons around Cagar Alam Pulau Dua. The research method was a combination of direct observation and "focal sampling" method using videotape (handycam). The result showed that foraging pattern of Casmerodius albus were as much 30 kinds, supreme pattern variation was found on the rice-field in the morning (17 type pattern), and the coming foraging pattern was PCa1. Foraging patterns in Egretta garzetta were 160 types, supreme variation to be met on mudflat in the morning (47 type pattern), and pattern type with supreme frequency was PEg1. However on the Bubulcus ibis, the number of foraging pattern were as much 65 types, with supreme variation found on rice-field in the morning ( 33 type pattern) and pattern type with supreme frequency was PBi15.

Keywords - foraging pattern, herons, variation, frequency

\section{PENDAHULUAN}

Setiap organisme memiliki kemampuan untuk Shidup, tumbuh dan berkembangbiak pada habitat yang sesuai dengannya. Salah satu cara untuk mempertahankan kelangsungan hidupnya adalah dengan mengkonsumsi makanan. Beberapa faktor yang berperan dalam menentukan perolehan makanan pada suatu organisme antara lain ketersediaan sumber makanan, kondisi lokasi mencari makan, waktu mencari makan, jenis pakan yang tersedia serta perilaku mencari makan yang dimiliki. Faktor-faktor tersebut diduga mampu mempengaruhi keberhasilan makan suatu organisme. Demikian juga bagi ketiga jenis kuntul yang terdapat di Cagar Alam Pulau Dua, sumber bahan makanan yang dibutuhkan untuk kelangsungan hidupnya tersedia di daerah sekitar kawasan tersebut.

Pulau Dua yang terletak di Teluk Banten Pantai Utara Jawa Barat merupakan salah satu daerah lahan basah yang telah ditetapkan sebagai wilayah utama bagi konservasi burung-burung air pada tahun 1937, berdasarkan keputusan Gubenur Jenderal Hindia Belanda tanggal 30 Juli 1937 No. $21 \mathrm{Stbl} 474$ [1] [2]. 
Secara geografis Pulau Dua terletak pada koordinat antara $06^{\circ} 01^{\prime} \mathrm{LS}$ dan $106^{\circ} 12^{\prime} \mathrm{BT}$, merupakan dataran rendah dengan luas sekitar 30 ha. Vegetasi yang tumbuh pada kawasan tersebut merupakan komunitas mangrove, $60 \%$ didominasi oleh Rhizopora apiculata khususnya pada bagian selatan pulau, sedangkan pada bagian timur ditumbuhi oleh Avicenia marina.

Terdapat 12 jenis burung air yang menghuni Cagar Alam Pulau Dua, yaitu Anhinga melanogaster, Phalacrocorax spp, Ardea cinerea, A. purpurea, Bubulcus ibis, Egretta garzetta, E. intermedia, E. sacra, Casmerodius albus, Nycticorax nycticorax, Threskiornis melanocephalus dan Plegadis falcinellus [3].

Burung air yang terdapat pada lokasi ini sebagian besar bersifat predator karena memangsa berbagai jenis ikan dan hewan kecil lainnya termasuk kodok, cacing, udang, kepiting. Beberapa area di sekitar Cagar Alam Pulau Dua yang menjadi lokasi makan koloni burung air merupakan sumber penghidupan masyarakat setempat antara lain tambak, muara sungai, rawa dan kolam air payau. Sehingga kehadirannya sering dianggap sebagai hama dan diburu. Seiring dengan berkembangnya Pulau Dua sebagai kawasan Cagar Alam serta adanya pemanfaatan wilayah sekitar Cagar Alam oleh penduduk setempat, maka diperlukan usaha perlindungan bagi keberadaan populasi burung air pada daerah tersebut.

Berdasarkan penelitian yang dilakukan terhadap aktivitas makan yang dilakukan tiga jenis kuntul (Casmerodius albus, Egretta garzetta, Bubulcus ibis) yang mencari makan di sekitar kawasan Cagar Alam Pulau Dua Serang diperoleh serangkaian aktivitas yang membentuk suatu pola pada saat mencari makan. Pola mencari makan merupakan faktor yang berasal dari hewan itu sendiri. Setiap hewan mempunyai variasi pola mencari makan yang berbeda sesuai dengan anatomi dan morfologi tubuh yang dimilikinya. Seperti halnya pada tiga jenis kuntul yang menghuni kawasan Cagar Alam Pulau Dua, variasi pola yang tampak pada saat mencari makan akan berbeda antara satu spesies dengan spesies yang lain, juga dengan pola makan yang dimiliki burung lain.

Penelitian ini bertujuan untuk mengetahui variasi pola mencari makan pada tiga jenis kuntul (Casmerodius albus, Egretta garzetta, Bubulcus ibis) yang mencari makan di sekitar kawasan Cagar Alam Pulau Dua, Serang.

\section{TINJAUAN PUSTAKA}

Aktivitas mencari makan merupakan bagian dari aktivitas harian yang dilakukan oleh seluruh hewan, termasuk burung air. Burung air pada umumnya mencari makan pada kawasan yang memiliki ekosistem gabungan dari tiga jenis perairan yaitu perairan tawar, payau dan laut seperti daerah bakau. Ada juga yang mencari makan di sungai, danau, waduk, rawa pasang surut, dan teluk [4].

Lokasi mencari makan pada burung biasanya dipilih berdasarkan perbedaan bentuk dan ukuran tubuh yang dimiliki setiap spesies serta jenis makanan yang disukai [5]. Proses pencarian makan yang dilakukan oleh sebagian besar burung air terjadi pada daerah perairan dangkal di sekitar pantai. Hal ini berkaitan dengan keberadaan hewanhewan air yang hidup di daerah tersebut yang merupakan mangsa bagi burung-burung tersebut [6].

Ketiga jenis kuntul yang diamati pada daerah di sekitar Cagar Alam Pulau Dua memiliki lokasi mencari makan yang berupa daerah perairan dangkal dan terbuka seperti sawah, tambak dan dataran lumpur, serta tegalan (khusus pada B. ibis). Hal ini berhubungan dengan jenis makanan yang menjadi mangsanya.

Perilaku makan adalah penampakan tingkah laku dalam kaitannya dengan aktivitas makan. Aktivitas makan itu sendiri merupakan bagian dari aktivitas harian. Pada burung umumnya aktivitas tersebut dilakukan pada pagi hingga sore hari, kecuali pada beberapa jenis burung malam 'nocturnal' [7].

Perilaku makan pada makhluk hidup mencakup semua proses konsumsi bahan makanan yang bermanfaat dalam bentuk padat atau cair [8]. Perilaku makan binatang sangat bervariasi baik lamanya makan maupun frekuensi tingkah laku pada saat makan. Perilaku makan dari tiap-tiap spesies hewan memiliki cara-cara yang spesifik. Faktor yang mempengaruhi berbedanya cara makan antara lain morfologi hewan yang mencari makan, rangsangan dari makanan itu sendiri dan faktor dari dalam tubuh hewan yang akan memberikan urutan gerak tubuh pada binatang tersebut [9].

Secara umum terdapat tiga macam perilaku makan yang tampak pada famili Ardeidae yaitu, berdiri atau mengikuti mangsa 'stand or stalk feeding', mengganggu dan memburu mangsa 'disturb and chase feeding' serta menangkap mangsa di udara 
dan di bawah perairan 'aerial and deep water feeding'. Ketiga perilaku ini merupakan karakteristik aktivitas makan yang dimiliki oleh famili Ardeidae [10].

\section{METODE PENELITIAN}

Penelitian dilakukan di kawasan Cagar Alam Pulau Dua dan sekitarnya yang dimanfaatkan oleh tiga jenis kuntul yaitu adalah Kuntul Besar Casmerodius albus, kuntul kecil Egretta garzetta dan kuntul kerbau Bubulcus ibis sebagai lokasi mencari makan. Penelitian berlangsung selama 12 bulan.

Peralatan yang digunakan adalah: Kamera "Canon EOS lensa 600 mm", Handycam corder Sony digital zoom 180, Tripod Manfrotto, Monokuler Swift 60 x 80, Binokuler Nikon 5,12 x 24, tenda pengamatan terbuat dari kain, video player, TV Sony 14", kendaraan roda 2 dan roda 4 , lembar data dan alat tulis.

\subsection{Studi Pendahuluan}

Dilakukan selama 2 bulan bertujuan untuk mengetahui lokasi yang dijadikan sebagai tempat mencari makan bagi tiga jenis kuntul serta untuk menentukan lokasi pengambilan data dan rekaman gambar.

\subsection{Pengambilan Gambar}

Dilakukan selama 10 bulan, dengan memilih satu individu sasaran (focal observation method) selama waktu 5 menit dan kelipatannya, dilanjutkan individu terdekat [11]. Pengambilan gambar difokuskan pada perilaku mencari makan yang dilakukan oleh ketiga jenis kuntul.

\subsection{Analisis Rekaman Gambar}

Gambar rekaman disunting untuk menentukan sekuen yang layak dianalisis. Rekaman dianalisis setiap jangka waktu lima menit. Data yang dikumpulkan meliputi: perilaku mencari makan tiga jenis kuntul di kawasan Cagar Alam Pulau Dua dan sekitarnya serta frekuensi aktivitas yang dilakukan burung tersebut.

\section{HASIL DAN PEMBAHASAN}

Pola mencari makan yang dilakukan oleh ketiga macam kuntul yang diamati sangat bervariasi. Setiap pola mencari makan terdiri atas serangkaian aktivitas yang dilakukan berkaitan dengan kegiatan mencari makan. Setiap pola mencari makan diawali oleh aktivitas melangkah dan diikuti oleh aktivitasaktivitas lain termasuk aktivitas mematuk mangsa.

Jumlah variasi pola mencari makan pada Casmerodius albus yang dijumpai selama pengamatan adalah sebanyak 30 macam (Tabel 1). Dari 30 jenis pola tersebut 12 macam diantaranya diakhiri dengan aktivitas minum, 10 macam diakhiri dengan aktivitas menelan, lima macam pola diakhiri dengan berhenti, dan selebihnya diakhiri dengan mangsa terlepas atau patuk gagal (Tabel lampiran 1).

Berdasarkan perbedaan lokasi dan waktu mencari makan, jumlah dan variasi pola mencari makan yang tampak berbeda-beda. Variasi pola mencari makan pada Casmerodius albus tertinggi dijumpai di sawah waktu pagi yaitu sebanyak 17 macam. Pada lokasi tambak waktu pagi dan tambak pada sore hari, dijumpai sebanyak 11 macam variasi pola. Sedangkan pada lokasi tambak waktu siang tidak dijumpai satu pun pola makan, hal ini berkaitan dengan tidak dijumpainya aktivitas makan pada lokasi dan waktu tersebut (Gambar 1).

Tabel 1. Jumlah variasi pola mencari makan ketiga jenis kuntul

\begin{tabular}{cc}
\hline Jenis Kuntul & Variasi pola mencari makan \\
\hline Casmerodius albus & 30 \\
Egretta garzetta & 160 \\
Bubulcus ibis & 65 \\
\hline
\end{tabular}

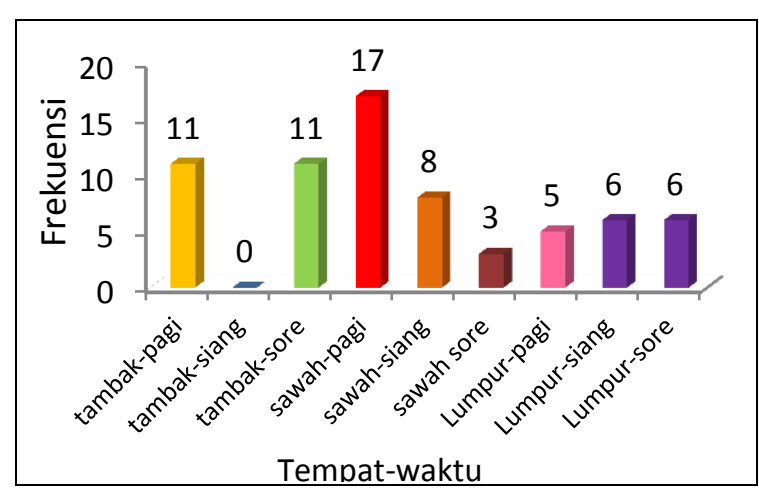

Gambar 1. Jumlah variasi pola mencari makan Casmerodius albus pada setiap lokasi makan 
Jenis pola mencari makan yang sering terlihat pada Casmerodius albus saat pengamatan di seluruh lokasi adalah sebanyak lima jenis, yaitu PCa1 (langkah-patuk gagal), PCa5 (langkah-patuk sukses-telan), PCa10 (langkah-patuk suksesmemegang-menelan), PCa11 (langkah-patuk sukses-memegang-menelan-minum) dan $\mathrm{PCa} 27$ (langkah-berhenti-patuk sukses-memegangmenelan) (Tabel lampiran 1).

Berdasarkan frekuensi terjadinya, pola mencari makan pertama PCa1 merupakan pola dengan frekuensi kejadiannya tertinggi pada saat pengamatan, yaitu sebanyak 93 kali, diikuti pola PCa5 dengan frekuensi kejadian sebanyak 69 kali, selanjutnya PCa10 dengan frekuensi sebanyak 14 kali. Sedangkan PCa11 dan PCa27 terlihat pada saat pengamatan dengan frekuensi masing-masing sebanyak 7 kali dan PCa7 terlihat dengan frekuensi sebanyak 5 kali (Gambar 2).

Jenis pola mencari makan dengan jumlah kejadian tertinggi pada setiap lokasi juga berbeda. Pada lokasi tambak waktu pagi, tambak waktu sore dan lumpur waktu sore, jenis pola yang memiliki frekuensi tertinggi adalah PCa1, masing-masing dengan jumlah frekuensi pola sebanyak 20,37 dan 3. Sedangkan pada lokasi sawah waktu pagi, sawah waktu sore dan lumpur waktu siang, jenis pola yang memiliki frekuensi tertinggi adalah PCa5. Jumlah frekuensi pada masing-masing lokasi adalah 28, 19 dan 14 (Gambar 3).

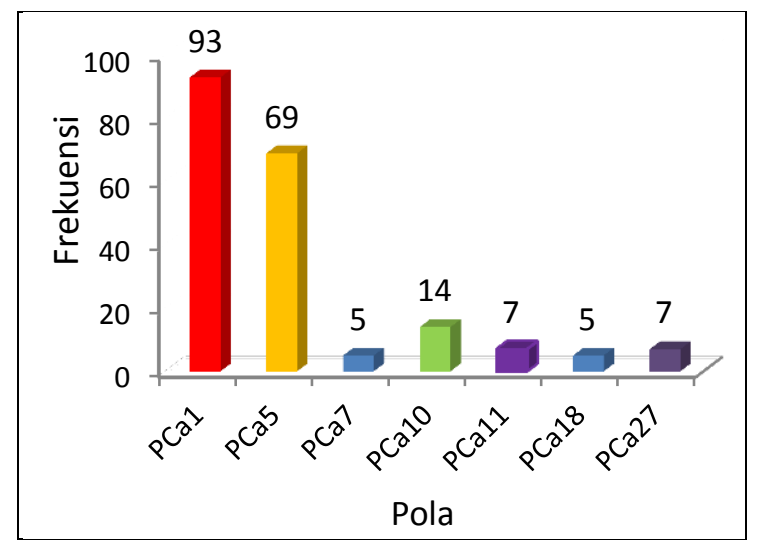

Gambar 2. Pola mencari makan Casmerodius albus yang banyak dijumpai selama pengamatan

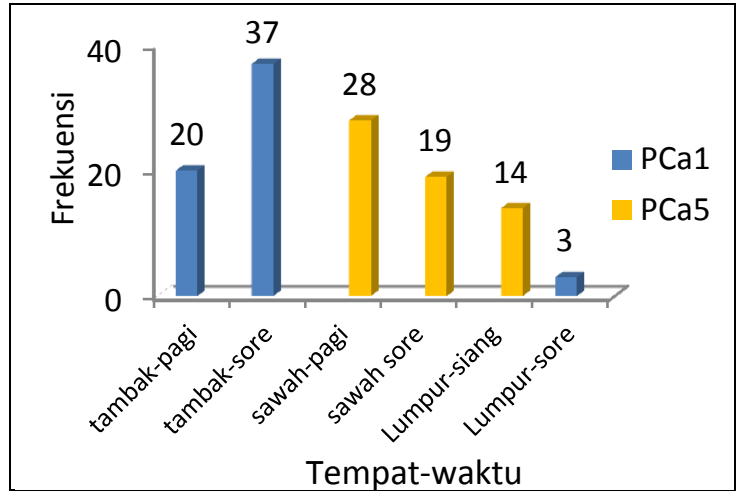

Gambar 3. Macam pola makan Casmerodius albus dengan frekuensi tertinggi pada tiap lokasi

Variasi pola makan yang dijumpai pada Egretta garzetta merupakan variasi pola terbanyak yang terjadi selama pengamatan dibanding dengan dua jenis kuntul lain, yaitu sebanyak 160 macam (Tabel 1). Dari jumlah tersebut pola terbanyak diakhiri oleh aktivitas patuk gagal yaitu sebanyak 50 macam, 48 macam diakhiri oleh aktivitas telan, 24 macam diakhiri aktivitas berhenti, 16 macam pola diakhiri aktivitas minum, selebihnya diakhiri aktivitas membersihkan bulu, tidak aktif, buang kotoran, terbang dan tidak aktif (Tabel lampiran 2).

Berdasarkan perbedaan lokasi dan waktu mencari makan, jumlah dan variasi pola mencari makan yang tampak adalah sebagai berikut variasi pola mencari makan tertinggi dijumpai di lumpur waktu pagi yaitu sebanyak 47 macam pola mencari makan. Berikutnya pada lokasi lumpur waktu siang, yaitu sebanyak 45 macam pola makan, pada lokasi sawah waktu pagi sebanyak 39 macam pola mencari makan. Jumlah variasi pola terendah dijumpai pada lokasi tambak waktu siang hari, yaitu hanya dijumpai 27 pola mencari makan. (Gambar 4).

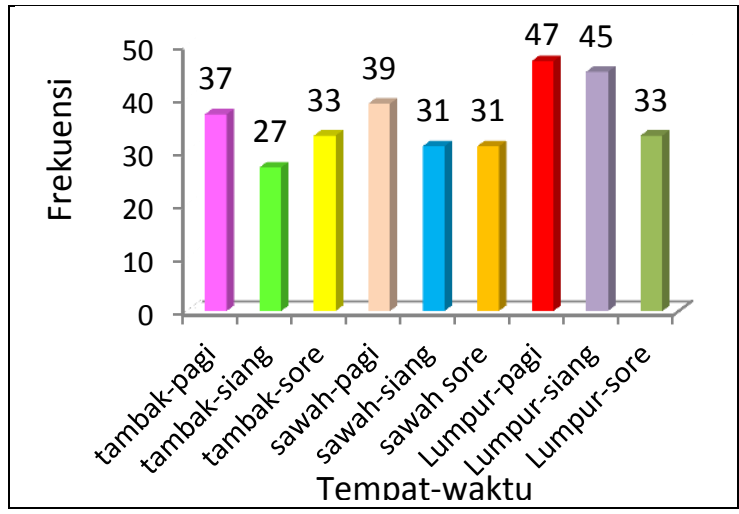

Gambar 4 . Jumlah variasi pola mencari makan Egretta garzetta pada setiap lokasi makan 
Jenis pola mencari makan pada Egretta garzetta yang dilakukan pada semua lokasi makan dan banyak frekuensinya pada saat pengamatan di seluruh lokasi adalah lima jenis pola, yaitu PEg1 (langkah-patuk gagal), PEg48 (langkah-patuk sukses-telan), PEg87 (langkah-berhenti-patuk gagal), PEg133 (memutar kaki-patuk gagalberhenti) dan PEg145 (Memutar kaki-patuk suksestelan berhenti) (Tabel lampiran 2).

Berdasarkan frekuensi terjadinya, pola mencari makan PEg1 merupakan pola dengan frekuensi kejadiannya tertinggi selama pengamatan berlangsung, yaitu sebanyak 800 kali, diikuti pola PEg48 dengan frekuensi kejadian 514 kali, PEg133 sebanyak 207 kali, PEg87 sebanyak 129 kali dan PEg145 dengan jumlah frekuensi kejadian 111 kali (Gambar 5).

Jenis pola mencari makan pada Egretta garzetta dengan frekuensi tertinggi berdasarkan perbedaan lokasi makan adalah, pada lokasi tambak waku pagi jenis pola makan yang paling sering dilakukan adalah memutar kaki-patuk gagal-berhenti (PEg133) dengan jumlah kejadian 97 kali. Sedangkan pada lokasi tambak waktu siang, tambak waktu sore, sawah waktu pagi, sawah waktu siang, sawah waktu sore, lumpur waktu pagi, lumpur waktu siang dan lumpur waktu sore. dan lumpur waktu sore, jenis pola mencari makan yang paling banyak dilakukan adalah langkah-patuk gagal (PEg1) dengan jumlah kejadian berbeda-beda untuk setiap lokasi (Gambar 6).

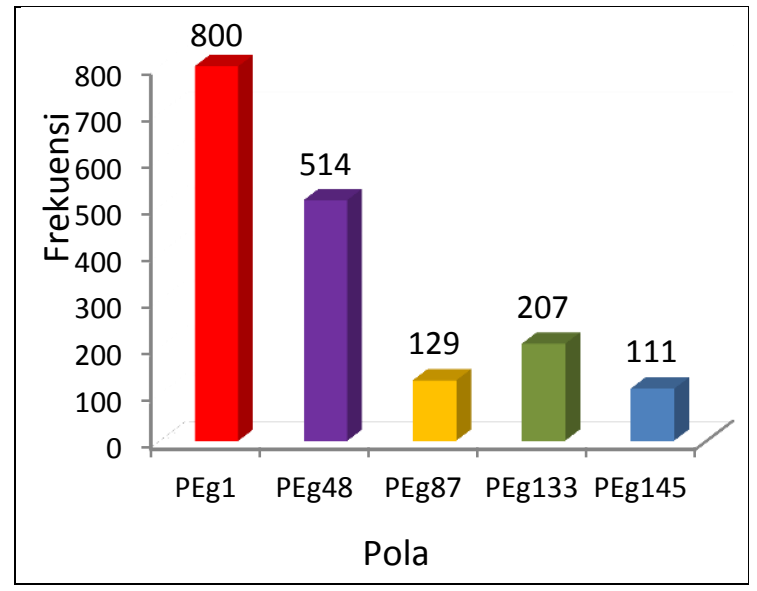

Gambar 5. Pola mencari makan Egretta garzetta yang banyak dijumpai selama pengamatan

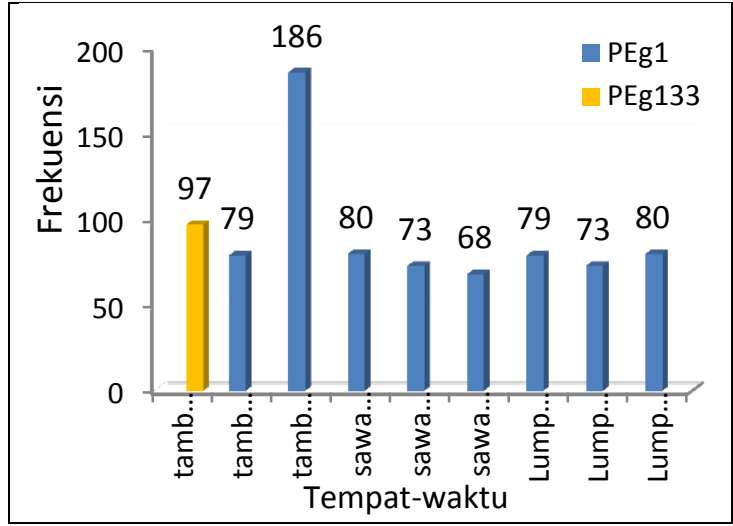

Gambar 6. Jenis pola makan Egretta garzetta dengan frekuensi tertinggi pada tiap lokasi

Variasi pola mencari makan yang dilakukan oleh $B$. ibis selama pengamatan berjumlah 65 macam (Tabel 1). Pola mencari makan yang diakhiri oleh aktivitas telan merupakan pola terbanyak yang dilakukan yaitu sebanyak 25 macam, pola yang diakhiri dengan berhenti sebanyak 16 macam, pola yang diakhiri aktivitas patuk gagal sebanyak sembilan macam. Sembilan macam pola mencari makan diakhiri dengan aktivitas tidak aktif, sedang yang diakhiri dengan aktivitas minum sebanyak enam macam pola dan dua macam pola diakhiri dengan aktivitas membersihkan bulu (Tabel Lampiran 3).

Berdasarkan perbedaan lokasi dan waktu mencari makan, jumlah dan variasi pola mencari makan yang tampak pada Bubulcus ibis adalah sebagai berikut variasi pola mencari makan tertinggi dijumpai di lokasi sawah waktu pagi yaitu sebanyak 32 macam pola mencari makan. Berikutnya pada lokasi sawah waktu sore, yaitu sebanyak 30 macam pola makan, pada lokasi tegalan waktu pagi sebanyak 27 macam pola Jumlah variasi pola terendah dijumpai pada lokasi sawah waktu siang hari, yaitu hanya dijumpai 7 pola mencari makan. (Gambar 7).

Macam pola mencari makan Bubulcus ibis yang dilakukan pada semua lokasi makan selama pengamatan sebanyak tiga, yaitu melangkah-patuk gagal (PBi1), melangkah-patuk sukses-telan (PBi15), dan melangkah-berhenti-patuk gagal (PBi38) (Tabel lampiran 3).

Berdasarkan frekuensi terjadinya, pola mencari makan PBi15 pada Bubulcus ibis merupakan macam pola dengan frekuensi kejadiannya tertinggi selama pengamatan berlangsung, yaitu sebanyak 
200 kali, diikuti pola PBi1 dengan frekuensi kejadian 62 kali, PBi52 sebanyak 27 kali, PBi38 sebanyak 24kali, PBi18 sebanyak 22 kejadian dan PBi2 dengan jumlah frekuensi kejadian 14 kali (Gambar 8).

Macam pola mencari makan pada Bubulcus ibis dengan frekuensi tertinggi berdasarkan perbedaan lokasi makan adalah, PBi15 (melangkah-patuk sukses-telan). Macam pola makan ini dijumpai pada lokasi sawah waktu pagi sebanyak 100 kejadian, sawah waktu sore sebanyak 42 kejadian, sawah waktu siang sebanyak 21 kejadian, tegalan waktu pagi sebanyak 24 kejadian dan tegalan waktu sore dengan jumlah kejadian 4 kali. Macam pola PBi16 (melangkah-patuk sukses-telan-berhenti) paling sering dilakukan pada lokasi tegalan waktu siang hari, dengan jumlah kejadian 12 kali (Gambar 9).

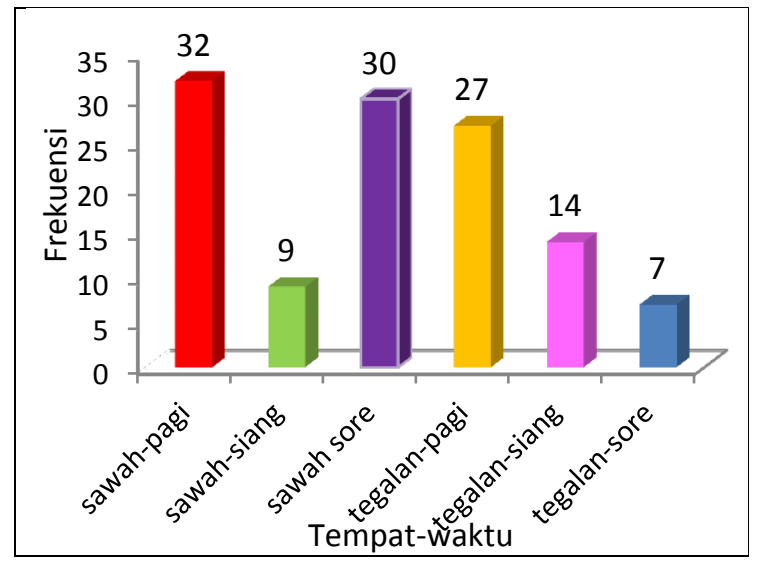

Gambar 7. Jumlah variasi pola mencari makan Bubulcus ibis pada setiap lokasi makan

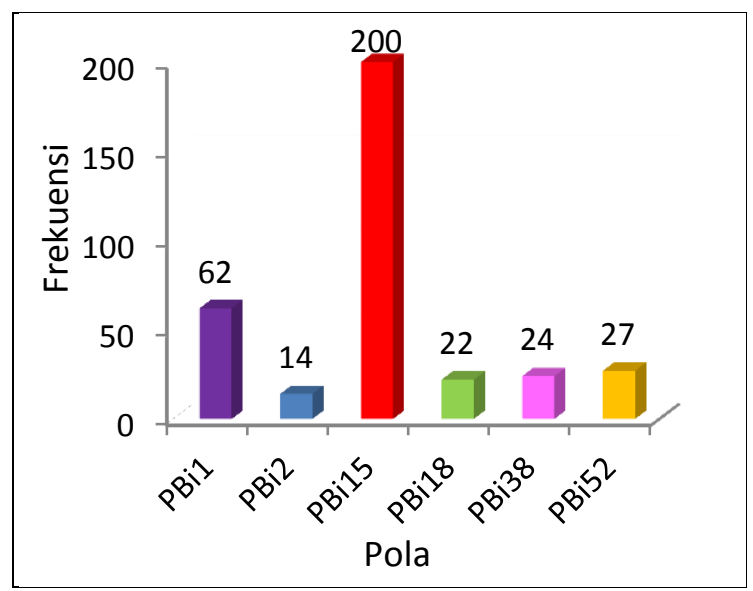

Gambar 8. Pola mencari makan Bubulcus ibis yang banyak dijumpai selama pengamatan

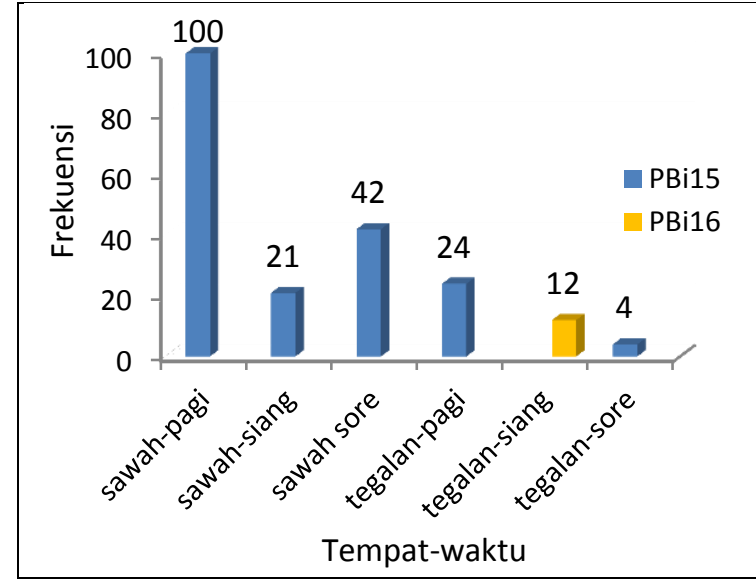

Gambar 9. Macam pola makan Bubulcus ibis dengan frekuensi tertinggi pada tiap lokasi

Pola mencari makan yang tampak pada ketiga macam kuntul menunjukkan jumlah yang bervariasi (Tabel 1). Variasi yang dijumpai pada pola-pola tersebut berkaitan dengan macam aktivitas mencari makan yang dilakukan, oleh masing-masing jenis kuntul. Aktivitas yang dilakukan antara lain meliputi melangkah, mematuk, berhenti melangkah, menelan, memegang mangsa, mencelup paruh, dan terbang [12].

Pola mencari makan adalah bagian dari aktivitas makan, karena setiap pola mencari makan terdiri atas serangkaian aktivitas yang dilakukan pada saat kegiatan mencari makan. Masing-masing pola mencari makan diawali oleh aktivitas melangkah dan diikuti aktivitas lain [13].

Ragam dan jumlah pola mencari makan yang tampak pada ketiga jenis kuntul cukup bervariasi. Perbedaan tersebut berkaitan dengan aktivitas dan perilaku mencari makan ketiga macam kuntul. Casmerodius albus dengan perilaku makan spesifik berdiri dan menunggu mangsa serta berjalan pelan, memiliki ragam dan pola mencari makan yang lebih sedikit yaitu sebanyak 30 pola dibandingkan E. garzetta dan B. ibis yang memiliki tipe perilaku mencari makan mengejar dan berburu mangsa. Ragam pola mencari makan yang tampak pada $E$. garzetta dan B. ibis masing-masing sebanyak 160 pola dan 65 pola (Tabel 1).

Pola mencari makan yang terdiri dari aktivitas langkah patuk gagal (pola pertama) merupakan ragam pola dengan frekuensi kejadian paling tinggi pada $C$ albus dan E. garzetta. Sedangkan pada $B$. ibis pola yang terdiri dari aktivitas langkah patuk 
telan merupakan ragam pola dengan frekuensi kejadian tertinggi.

Kedua macam pola ini berkaitan dengan aktivitas melangkah dan aktivitas mematuk yang merupakan karakteristik perilaku mencari makan pada sebagian besar burung. Pola mencari makan yang terdiri lebih dari empat macam aktivitas memperlihatkan jumlah kejadian yang lebih sedikit.

Bagi ketiga macam kuntul variasi pola mencari makan lebih banyak dijumpai pada waktu pagi hari. Berdasarkan lokasi dan waktu mencari makan secara bersamaan pada $C$. albus, ragam pola mencari makan lebih banyak dijumpai di sawah waktu pagi (17 macam), E. garzetta di dataran lumpur waktu pagi (47 macam) dan $B$. ibis di sawah waktu pagi (33 macam). Hal ini menunjukkan bahwa pada pagi hari aktivitas mencari makan yang dilakukan lebih tinggi sehingga pola mencari makan yang tampak juga lebih bervariasi dibandingkan pada waktu siang dan sore.

Pola mencari makan dengan rangkaian aktivitas terbanyak yang dilakukan oleh $C$. albus dijumpai pada pola ke-28, terdiri dari 14 macam aktivitas. Pada E. garzetta dijumpai pada pola ke-58 yang terdiri dari 16 macam aktivitas sedangkan pada $B$. ibis jumlah pola dengan aktivitas terbanyak dijumpai pada pola ke-63, yang terdiri dari 12 macam aktivitas (Tabel lampiran 3). Banyaknya aktivitas yang dijumpai pada setiap pola dipengaruhi oleh macam mangsa yang dikonsumsi dan perilaku mencari makan yang dilakukan pada saat itu.

Pola-pola yang terjadi saat mencari makan seringkali menunjukkan aktivitas yang sangat kompleks. Salah satu faktor yang berpengaruh terhadap perubahan pola mencari makan adalah perilaku mencari makan yang dimiliki kuntul tersebut [14].

Pada kuntul suatu pola makan dapat saja dimulai dengan aktivitas yang menampakkan perilaku mengganggu mangsa yaitu menggerakkan kaki dengan menurun-naikkan kaki 'foot padling' sambil berdiri selanjutnya mengepakkan sayap dengan keras dan melompat secara periodik (berulang). Apabila mangsa sudah terlihat dilanjutkan dengan menusuk mangsa dengan paruhnya dan membawa mangsa ke darat [15].

\section{KESIMPULAN}

Pola mencari makan yang tampak pada $C$. albus adalah sebanyak 31 macam, jumlah pola mencari makan tertinggi terjadi di sawah waktu pagi (17 macam), dan macam pola mencari makan yang memiliki frekuensi tertinggi adalah PCa1. Pola mencari makan yang dilakukan E. garzetta sebanyak 160 macam, Jumlah pola mencari makan tertinggi terjadi di dataran lumpur waktu pagi sebanyak 47 macam, dan pola mencari makan PEg1 merupakan macam pola yang memiliki frekuensi kejadian tertinggi. Sedangkan pola mencari makan yang dilakukan $B$. ibis sebanyak 65 macam, variasi tertinggi terjadi di sawah waktu pagi sebanyak 33 pola, dan macam pola dengan frekuensi kejadian tertinggi adalah PBi15.

\section{UCAPAN TERIMAKASIH}

Penelitian ini dilakukan di kawasan Cagar Alam Pulau Dua Serang, Propinsi Banten di bawah bimbingan Prof. Dr. Nawangsari Sugiri, Dr. Ani Mardiastuti, Dr. Dewi Malia Prawiradilaga. Penelitian ini merupakan bagian dari Teluk Banten Programme Waterbird Research 1997-2001 yang dipimpin oleh Drs. Yus Rusila Noor (Wetlands International-Indonesia Programme) dan didanai oleh NIOZ (The Netherland Institut for Sea Research) dan WOTRO (Netherlands Foundations for The Advancement of Tropical Research). Untuk itu dengan penuh rasa hormat saya mengucapkan banyak terimakasih atas segala bimbingan dan bantuannya sehingga penelitian ini dapat terlaksana dengan baik.

\section{DAFTAR ACUAN / PUSTAKA}

[1] Milton R and A Marhadi. The Bird Life of The Nature Reserve Pulau Dua. Kukila 1985 (2). Jakarta: Indonesia Ornithological Soc. 1985.

[2] Partomihardjo. T. Formasi Vegetasi di Cagar Alam Pulau Dua, Serang Jawa Barat. Media Konservasi $2: 10-15.1986$.

[3] Rusila Noor Y. Pengetahuan Tentang Bururng Air Khususnya Burung air Bermigrasi (Migratory Waterbirds) di Indonesia. Makalah Disajikan pada Wetlands Conservations Assesment and Management Training Course III, Bororg 03 September 1994. Pusdiklat Pegawai \& SDM Kehutanan Bogor :PHPA/AWB. 1994.

[4] Davies JG, Claridge dan CHE Niranita. Manfaat Lahan Basah dalam Mendukung dan Memelihara 
Pembangunan. Direktorat Jendral PHPA Indonesia: Asian Wetlands Bureau. 1996.

[5] Scoot, D. The Feeding Succes of Cattle Egret in Flock. Anim. Behav. 32 : 1089-1100. 1984

[6] Ismanto, A. Population dan Habitat Burung Merandai di Rawa Gombor Jawa Tengah [Laporan Penelitian]. Yogyakarta : Universitas Gajah Mada, Fakultas Biologi. 1990.

[7] Powell, G.V.N. Habitat Use by Wading Birds in A Subtropical Estuary: Implication of Hidrography. Auk 104: 740-749. 1986.

[8] Tanudimadja, K dan S. Kusumamihardja. Perilaku Hewan Ternak. Jurusan Anatomi. Fakultas Kedokteran Hewan. Bogor : Institut Pertanian Bogor. 1985.

[9] Suratmo, F. G.. Prinsip Dasar Tingkah Laku Satwa Liar. Bogor : Institut Pertanian Bogor. 1979.

[10] Kushlan J. Feeding Behaviour of North American Heron. Auk 93, 86-93. 1976

[11] Altmann, J. Observational Study of Behavior: Sampling Methods. Behaviour 49:227-269. 1974.
[12] Elfidasari D. Perilaku Makan Kuntul Sedang (Egretta intermedia) dan Kuntul Kecil (Egretta garzetta) Serta Keberhasilan Makan Pada Lingkungan Perairan di Banda Aceh dan Aceh Besar. Skripsi. Jurusan Biologi FMIPA Universitas Syiah Kuala, Banda Aceh. 1997.

[13] Elfidasari D. Ekologi dan Perilaku Mencari Makan Tiga Macam Kuntul di Daerah Sekitar Cagar Alam Pulau Dua Serang, Propinsi Banten. Tesis. Program Studi Biologi Program Pascasarjana Institut Pertanian Bogor, Bogor. 2001.

[14] Hancock J and J Kushlan. The Herons Handbook. London : Nicholas Enterprise/London. 1984.

[15] Hancock J. Aerial Stretch Display of The Eastern Race of The Great White Egret (Egretta alba). Ibis, 126, 92-94. 1982. 
Tabel lampiran 1. Pola mencari makan yang dilakukan Casmerodius albus

\begin{tabular}{|c|c|c|c|c|c|c|c|c|c|c|c|c|}
\hline No & POLA MAKAN & Kode & 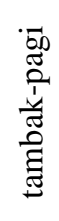 & 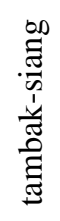 & 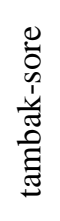 & 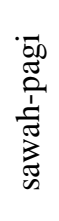 & 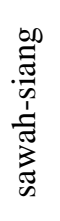 & 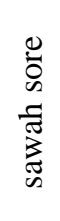 & 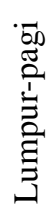 & 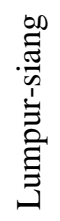 & 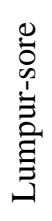 & $\stackrel{\pi}{0}$ \\
\hline 1 & St-Sf & PCa1 & 20 & & 37 & 16 & & 6 & 3 & 8 & 3 & 93 \\
\hline 2 & St-Sf-S & $\mathrm{PCa} 2$ & & & & 1 & & & & & & 1 \\
\hline 3 & St-Sf-Ss-H-Sw & $\mathrm{PCa} 3$ & & & & 1 & & & & & & 1 \\
\hline 4 & St-Sf-Sf-Ss-H-Sw & $\mathrm{PCa} 4$ & & & & 1 & & & & & & 1 \\
\hline 5 & St-Ss-Sw & PCa5 & 2 & & 1 & 28 & 1 & 19 & 3 & 14 & 1 & 69 \\
\hline 6 & St-Ss-Sw-Dr & $\mathrm{PCa} 6$ & & & & 2 & & & & & & 2 \\
\hline 7 & St-Ss-Sw-S & $\mathrm{PCa} 7$ & 1 & & & 3 & 1 & & & & & 5 \\
\hline 8 & St-Ss-Sw-Ss-Sw & $\mathrm{PCa} 8$ & & & & 3 & & & & & & 3 \\
\hline 9 & St-Ss-Sw-S-Ss-H-Sw-S & $\mathrm{PCa} 9$ & & & & 1 & & & & & & 1 \\
\hline 10 & St-Ss-H-Sw & PCa10 & 2 & & 6 & 3 & & 1 & 1 & & 1 & 14 \\
\hline 11 & St-Ss-H-Sw-Dr & PCa11 & 2 & & 2 & 1 & & & 1 & & 1 & 7 \\
\hline 12 & St-Ss-H-Sw-S & PCa12 & & & 2 & 1 & 1 & & & & & 4 \\
\hline 13 & St-Ss-H-Sw-S-Dr & PCa13 & 1 & & & & & & & 1 & & 2 \\
\hline 14 & St-Ss-H-E & PCa14 & & & & & 1 & & & & & 1 \\
\hline 15 & St-Ss-H-Di-E & PCa15 & 1 & & 1 & & & & & & & 2 \\
\hline 16 & St-Ss-H-Di-Sw & PCa16 & & & & & 1 & & & & & 1 \\
\hline 17 & St-S-H-TL-Sw & PCa17 & & & 1 & & & & & & & 1 \\
\hline 18 & St-S-Sf & PCa18 & & & & 1 & & & 1 & 1 & 2 & 5 \\
\hline 19 & St-S-Ss-Sw & PCa19 & & & 1 & 2 & & & & 1 & & 4 \\
\hline 20 & St-S-Ss-Sw-S & $\mathrm{PCa} 20$ & & & & 1 & & & & & & 1 \\
\hline 21 & St-S-Ss-Sw-Dr & $\mathrm{PCa} 21$ & & & & & & & & 1 & 1 & 2 \\
\hline 22 & St-S-Ss-Sw-S-Dr & PCa22 & 1 & & & & & & & & & 1 \\
\hline 23 & St-S-Ss-Sw-Ss-Sw & $\mathrm{PCa} 23$ & & & & 1 & & & & & & 1 \\
\hline 24 & St-S-Ss-H-Di-Sw-S-Dr & $\mathrm{PCa} 24$ & & & & & 1 & & & & & 1 \\
\hline 25 & St-S-Ss-H-Di-Sw-Dr-S-Dr & $\mathrm{PCa} 25$ & & & & & 1 & & & & & 1 \\
\hline 26 & St-S-Ss-H-Di-E-Rh-Di-E-Rh-Di-Sw-S-Dr & $\mathrm{PCa} 26$ & & & & & 1 & & & & & 1 \\
\hline 27 & St-S-Ss-H-Sw & $\mathrm{PCa} 27$ & 5 & & 1 & 1 & & & & & & 7 \\
\hline 28 & St-S-Ss-H-Sw-Dr & $\mathrm{PCa} 28$ & 1 & & & & & & & & & 1 \\
\hline 29 & St-S-Ss-H-Sw-S-Dr & PCa29 & & & 1 & & & & & & & 1 \\
\hline 30 & St-S-Ss-H-E-S-Dr & PCa30 & 1 & & 1 & & & & & & & 2 \\
\hline & $\begin{array}{r}\text { TOT A L } \\
\end{array}$ & & 37 & $\mathbf{0}$ & 54 & 67 & 8 & 26 & 9 & 26 & 9 & 236 \\
\hline
\end{tabular}

Keterangan :

St langkah

Sf patuk gagal

S henti

Ss patuk sukses

Sw telan

$\mathrm{H}$ pegang

Dr minum

E mangsa lepas

Di celup

TL terbang terus mendarat

$\mathrm{Rh}$ tangkap lagi 
Tabel lampiran 2. Pola mencari makan yang dilakukan Egrettagarzetta

\begin{tabular}{|c|c|c|c|c|c|c|c|c|c|c|c|c|}
\hline NO & POLA MAKAN & Kode & 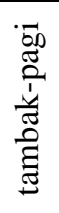 & 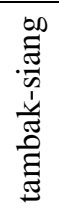 & 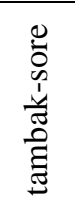 & 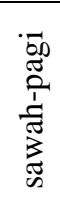 & 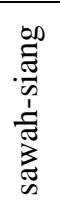 & $\begin{array}{l}0 \\
0 \\
\infty \\
\tilde{D} \\
\tilde{J} \\
\tilde{n} \\
0\end{array}$ & 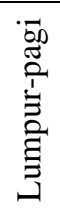 & 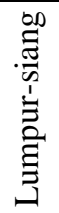 & 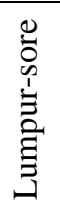 & $\stackrel{\pi}{0}$ \\
\hline 1 & St-Sf & PEg1 & 82 & 79 & 186 & 80 & 73 & 68 & 79 & 73 & 80 & 800 \\
\hline 2 & St-Sf-De & PEg2 & & & & & & & & & 1 & 1 \\
\hline 3 & St-Sf-S & PEg3 & & 2 & 5 & & 12 & 3 & 3 & 7 & & 32 \\
\hline 4 & St-Sf-S-Sf & PEg4 & 1 & & & 1 & & 1 & 1 & & & 4 \\
\hline 5 & St-Sf-S-Sf-S & PEg5 & & & 1 & & & & & & & 1 \\
\hline 6 & St-Sf-S-Sf-S-Sf & PEg6 & & & 1 & & & & & & & 1 \\
\hline 7 & St-Sf-S-Sf-S-Sf-S-Sf & PEg7 & & & & & & & & 1 & & 1 \\
\hline 8 & St-Sf-S-Sf-Sf-Sf-S & PEg8 & & & & & & 1 & & & & 1 \\
\hline 9 & St-Sf-S-Dr-Dr & PEg9 & & & & & & 1 & & & & 1 \\
\hline 10 & St-Sf-S-Ss-Sw & PEg10 & & & & & & & & 1 & & 1 \\
\hline 11 & St-Sf-S-Ss-H-Sw & PEg11 & & 1 & & & & & & & & 1 \\
\hline 12 & St-Sf-S-TL & PEg12 & & & 1 & & & & & & & 1 \\
\hline 13 & St-Sf-Ss-Sw & PEg13 & 5 & & 2 & 5 & 2 & 2 & 5 & 6 & 6 & 33 \\
\hline 14 & St-Sf-Ss-Sw-S & PEg14 & & 1 & & & & & & 2 & & 3 \\
\hline 15 & St-Sf-Ss-S-Ss-Sw-S & PEg15 & & & & & & & 1 & & & 1 \\
\hline 16 & St-Sf-Ss-Sw-Sf & PEg16 & 1 & & & & & & & 1 & & 2 \\
\hline 17 & St-Sf-Ss-Sw-Sf-Ss-Sw & PEg17 & 1 & & & & & & & & & 1 \\
\hline 18 & St-Sf-Ss-Sw-Sf-Sf-Sf-Sf-Ss-Sw & PEg18 & & & & & & & & 1 & & 1 \\
\hline 19 & St-Sf-Ss-Sw-Dr & PEg19 & & & & & & 1 & & & & 1 \\
\hline 20 & St-Sf-Ss-Sw-Ss-H-Sw & PEg20 & & 1 & & & & & & & & 1 \\
\hline 21 & St-Sf-Ss-Sw-Ss-Sw-S & PEg21 & & & & & & & 1 & & & 1 \\
\hline 22 & St-Sf-Ss-Sw-Ss-Sw-Sf-Sw-S & PEg22 & 1 & & & & & & & & & 1 \\
\hline 23 & St-Sf-Ss-H-Sw & PEg23 & 2 & & & & 5 & 5 & & 1 & & 13 \\
\hline 24 & St-Sf-Ia & PEg24 & & & & & 1 & 1 & & & & 2 \\
\hline 25 & St-Sf-Ia-Dr & PEg25 & & & & & 1 & & & & & 1 \\
\hline 26 & St-Sf-Ia-Tl-Ia & PEg26 & & & & & & 1 & & & & 1 \\
\hline 27 & St-Sf-Sf & PEg27 & 3 & 8 & 7 & 10 & & & 12 & 8 & 8 & 56 \\
\hline 28 & St-Sf-Sf-P & PEg28 & & & & 1 & & & & & & 1 \\
\hline 29 & St-Sf-Sf-Ss-Sw & PEg29 & & 1 & & 1 & & 2 & 1 & 2 & 3 & 10 \\
\hline 30 & St-Sf-Sf-Ss-Sw-Sf & PEg30 & & & & & 1 & & & & & 1 \\
\hline 31 & St-Sf-Sf-Ss-Sw-Sf-Sf-Ss-Sw & PEg31 & & & & & & & & & 2 & 2 \\
\hline 32 & St-Sf-Sf-Ss-Sw-Ss-Sw-Ia-Sf & PEg32 & & & & & 1 & & & & & 1 \\
\hline 33 & St-Sf-Sf-S-Sf & PEg33 & & & & 1 & & & 1 & & & 2 \\
\hline 34 & St-Sf-Sf-S-Ss-H-Sw & PEg34 & & & 1 & 6 & & & & & & 7 \\
\hline 35 & St-Sf-Sf-Ia-Sf-Sf-Sf & PEg35 & & & & & 1 & & & & & 1 \\
\hline 36 & St-Sf-Sf-Sf & PEg36 & & 1 & & & 2 & 3 & 9 & 3 & 1 & 19 \\
\hline 37 & St-Sf-Sf-Sf-S & PEg37 & & & & & & & 1 & & & 1 \\
\hline 38 & St-Sf-Sf-Sf-Ss-Sw & PEg38 & 1 & & & & & & & & 1 & 2 \\
\hline 39 & St-Sf-Sf-Sf-Ia-Sf-Sf-Ia & PEg39 & & & & & 1 & & & & & 1 \\
\hline 40 & St-Sf-Sf-Sf-Sf & PEg40 & & & 1 & 1 & & 2 & 1 & 1 & & 6 \\
\hline 41 & St-Sf-Sf-Sf-Sf-S & PEg41 & & & & 1 & & & & & & 1 \\
\hline 42 & St-Sf-Sf-Sf-Sf-Ss-Sw & PEg42 & & & & 1 & & & 1 & & & 2 \\
\hline 43 & $\begin{array}{l}\text { St-Sf(4)-Ss-Ss-S-Sf(6)-Ss-Sw-S- } \\
\text { Ss-Sw-Sf(5)-Ss-Sw-S }\end{array}$ & $\mathrm{PEg} 43$ & & & & & & & & 1 & & 1 \\
\hline 44 & St-Sf-Sf-Sf-Sf-Sf & PEg44 & & & & & & & 1 & 1 & & 2 \\
\hline 45 & St-Sf-Sf-Sf-Sf-Sf-Ia-Sf & PEg45 & & & & 1 & & & & & & 1 \\
\hline
\end{tabular}


Tabel lampiran 2. Pola mencari makan yang dilakukan Egrettagarzetta (lanjutan)

\begin{tabular}{|c|c|c|c|c|c|c|c|c|c|c|c|c|}
\hline NO & POLA MAKAN & Kode & 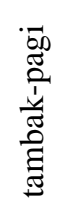 & 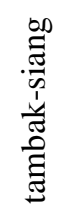 & 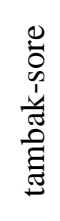 & 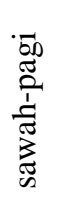 & 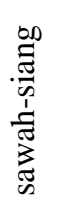 & 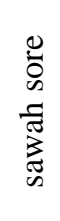 & 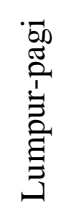 & 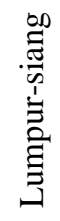 & 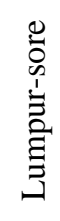 & $\stackrel{\Xi ّ}{0}$ \\
\hline 46 & St-Sf-Sf-Sf-Sf-Sf-Sf-Sf & PEg46 & & & & & & & 1 & & & 1 \\
\hline 47 & $\begin{array}{l}\text { St-Sf(7)-Ss-Sw-Sf(8)-Ss-Sw- } \\
\text { Sf(3)-Ss-Sw }\end{array}$ & PEg47 & & & & 1 & & & & & & 1 \\
\hline 48 & St-Ss-Sw & PEg48 & 49 & 20 & 82 & 77 & 41 & 46 & 63 & 92 & 44 & 514 \\
\hline 49 & St-Ss-Sw-Ia & PEg49 & & & & & & 3 & & & & 3 \\
\hline 50 & St-Ss-Sw-Dr & PEg50 & & & & 1 & & & & & 3 & 4 \\
\hline 51 & St-Ss-Sw-Dr-S & PEg51 & & & & & 1 & & & & & 1 \\
\hline 52 & St-Ss-Sw-Dr-Sf & PEg52 & & & & 1 & & & & & & 1 \\
\hline 53 & St-Ss-Sw-Dr-P & PEg53 & & & & & & & 1 & & & 1 \\
\hline 54 & St-Ss-Sw-Dr-Dr-Dr & PEg54 & & & & & & & 2 & & & 2 \\
\hline 55 & St-Ss-Sw-S & PEg55 & 4 & 1 & 8 & 2 & 1 & 2 & 3 & 5 & & 26 \\
\hline 56 & St-Ss-Sw-S-Sf & PEg56 & & & & & & & & 2 & & 2 \\
\hline 57 & St-Ss-Sw-S-Sf-Sf & PEg57 & & & 1 & & & & & & & 1 \\
\hline 58 & $\begin{array}{l}\text { St-Ss-Sw-S-Sf(6)-Ss-Sf(2)-Ss-Sw- } \\
\text { Sf(3)-Ss-Sw-Sf(9)-s-Sf(4)-S }\end{array}$ & PEg58 & & & & & & & 1 & & & 1 \\
\hline 59 & St-Ss-Sw-S-Ss-Sw & PEg59 & & 1 & & 1 & & & & 1 & & 3 \\
\hline 60 & St-Ss-Sw-S-Ss-Sw-Sf & PEg60 & & & & & & & 1 & & & 1 \\
\hline 61 & St-Ss-Sw-S-Ss-Sw-S-Ss-Sw & PEg61 & & & & 1 & & & & & & 1 \\
\hline 62 & $\begin{array}{l}\text { St-Ss-Sw-S-Ss-Sw-S-Ss-Sw-S-Sf- } \\
\text { S-Sf }\end{array}$ & PEg62 & & & & 1 & & & & & & 1 \\
\hline 63 & St-Ss-Sw-Sf & PEg63 & & & 1 & 1 & & 1 & & & 2 & 5 \\
\hline 64 & St-Ss-Sw-Sf-Ss-Sw & PEg64 & & & 1 & & & & & & & 1 \\
\hline 65 & St-Ss-Sw-Sf-Ss-Sw-Sf-Ss-Sw & PEg65 & & & & & & & & & 1 & 1 \\
\hline 66 & St-Ss-Sw-Sf-Ss-Sw-Sf-S-Sf & PEg66 & & & & & & & 1 & & & 1 \\
\hline 67 & St-Ss-Sw-Sf-Sf & PEg67 & & & & & & & 2 & & 1 & 3 \\
\hline 68 & St-Ss-Sw-Sf-Sf-Sf-Sf-Sf & PEg68 & & & & & & & 3 & & & 3 \\
\hline 69 & St-Ss-Sw-Sf-Sf-Sf-Sf-Sf-Sf-Sf-Sf & PEg69 & & & & 1 & & & & & & 1 \\
\hline 70 & St-Ss-Sw-Ss-Sw & PEg70 & 2 & & & 1 & 1 & 2 & 3 & 4 & 3 & 16 \\
\hline 71 & St-Ss-Sw-Ss-Sw-Dr & PEg71 & & & & & & & 1 & & & 1 \\
\hline 72 & St-Ss-Sw-Ss-Sw-Sf & PEg72 & & & & & & & 1 & & & 1 \\
\hline 73 & St-Ss-Sw-Ss-Sw-Sf-Sf & PEg73 & & & & & 1 & & & & & 1 \\
\hline 74 & St-Ss-Sw-Ss-Sw-Ss-Sw & PEg74 & & & & & & & & & 1 & 1 \\
\hline 75 & $\begin{array}{l}\text { St-Ss-Sw-Ss-Sw-Ss-Sw-Ss-Sw-Sf- } \\
\text { Sf-Sf-Sf }\end{array}$ & PEg75 & & & & & & & & & 1 & 1 \\
\hline 76 & St-Ss-Sw-P & PEg76 & & & & & & & & 1 & & 1 \\
\hline 77 & St-Ss-Sw-TL & PEg77 & & & & & & 2 & & & & 2 \\
\hline 78 & St-Ss-H-Sw & PEg78 & 8 & 32 & 10 & 1 & 1 & & & & 1 & 53 \\
\hline 79 & St-Ss-H-Sw-Dr & PEg79 & 2 & & 1 & & & & & & & 3 \\
\hline 80 & St-Ss-H-Sw-S & PEg80 & & 2 & & & & & & 1 & & 3 \\
\hline 81 & St-Ss-H-Sw-S-Dr & PEg81 & 2 & 1 & 1 & & & & & & & 4 \\
\hline 82 & St-Ss-H-Sw-Sw-S-Ia-P & PEg82 & & & & & & & 1 & & & 1 \\
\hline 83 & $\begin{array}{l}\text { St-Ss-H-Sw-Ss-H-Sw-Ss-H-Sw- } \\
\text { Dr }\end{array}$ & PEg83 & 1 & & & & & & & & & 1 \\
\hline 84 & St-Ss-H-Di-Sw-S & PEg84 & & & 1 & & & & & & & 1 \\
\hline 85 & St-Ss-H-E-Rh-Sw & PEg85 & & 1 & & & & & & & & 1 \\
\hline 86 & St-Ss-H-Di-E-Rh-H-Sw & PEg86 & 1 & & & & & & & & & 1 \\
\hline
\end{tabular}


Tabel lampiran 2. Pola mencari makan yang dilakukan Egrettagarzetta (lanjutan)

\begin{tabular}{|c|c|c|c|c|c|c|c|c|c|c|c|c|}
\hline NO & POLA MAKAN & Kode & 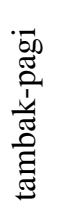 & 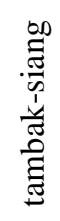 & 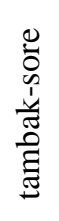 & 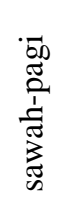 & 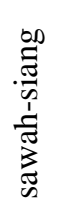 & 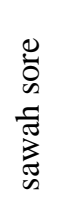 & 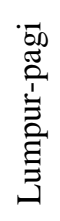 & 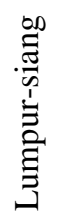 & 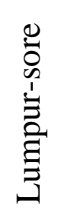 & $\stackrel{\Xi ّ}{\circ}$ \\
\hline 87 & St-S-Sf & PEg87 & 3 & 53 & 9 & 23 & 10 & 11 & 5 & 4 & 11 & 129 \\
\hline 88 & St-S-Sf-Ia & PEg88 & & & & 1 & 1 & & & & & 2 \\
\hline 89 & St-S-Sf-S & PEg89 & & 1 & 2 & & 1 & 1 & & 1 & & 6 \\
\hline 90 & St-S-Sf-S-Sf & PEg90 & & & & & & & & 1 & & 1 \\
\hline 91 & St-S-Sf-S-Dr & PEg91 & & & & & & & 1 & & & 1 \\
\hline 92 & St-S-Sf-S-Ss-Sw & PEg92 & & & 1 & & & & 1 & & & 2 \\
\hline 93 & $\begin{array}{l}\text { St-S-Sf-S-Ss-Sw-S-Sf-Ss-Sw-Sf- } \\
\text { Sf }\end{array}$ & PEg93 & & & & & & & 1 & & & 1 \\
\hline 94 & St-S-Sf-S-Ss-Dr-S-Dr-S & PEg94 & & & & & & & 1 & & & 1 \\
\hline 95 & St-S-Sf-Ss-Sw & PEg95 & & 2 & & & & 1 & 3 & & 1 & 7 \\
\hline 96 & St-S-Sf-Ss-H-Sw & PEg96 & & 1 & & & & & & & & 1 \\
\hline 97 & St-S-Sf-Sf & PEg97 & & & & 1 & 3 & 2 & 1 & & 2 & 9 \\
\hline 98 & St-S-Sf-Sf-S & PEg98 & & & & & & & 1 & & & 1 \\
\hline 99 & St-S-Sf-Sf-Ia & PEg99 & & & & & & & & 1 & & 1 \\
\hline 100 & St-S-Sf-Sf-Ss-Sw & PEg100 & & & & & & & & & 1 & 1 \\
\hline 101 & St-S-Sf-Sf-Sf & PEg101 & & & & & 1 & & & & & 1 \\
\hline 102 & St-S-Sf-Sf-Sf-Sf & PEg102 & & & & & 1 & & 2 & 1 & & 4 \\
\hline 103 & St-S-Sf-Sf-Sf-Sf-Sf-Ss-Sw & PEg103 & & & & & & & & & 1 & 1 \\
\hline 104 & St-S-Ss-Sw & PEg104 & 2 & 14 & 12 & 15 & 6 & 4 & 3 & 9 & & 65 \\
\hline 105 & St-S-Ss-Sw-S & PEg105 & & & & 1 & & & & & & 1 \\
\hline 106 & St-S-Ss-Sw-Ia & PEg106 & & & & 2 & & 1 & & & & 3 \\
\hline 107 & St-S-Ss-Sw-Ia-Dr-Ia & PEg107 & & & & & & & & & 1 & 1 \\
\hline 108 & St-S-Ss-Sw-Dr & PEg108 & & & & & & & 1 & & & 1 \\
\hline 109 & St-S-Ss-Sw-Sf-Ia-Sf & PEg109 & & & & & 1 & & & & & 1 \\
\hline 110 & St-S-Ss-Sw-Sf-Sf-Sf-Sf-Sf-Sf-Sf & PEg110 & & & & & & & & 1 & & 1 \\
\hline 111 & St-S-Ss-Sw-Ss-Sw & PEg111 & & 1 & & 1 & & & 1 & & & 3 \\
\hline 112 & St-S-Ss-Sw-Ss-Sw-Sf-Sf-Sf-Sf & PEg112 & & & & & & & 1 & & & 1 \\
\hline 113 & St-S-Ss-H-Sw & PEg113 & & 9 & 1 & & & & 1 & & & 11 \\
\hline 114 & St-S-Ss-H-Sw-Sf & PEg114 & & 1 & & & & & & & & 1 \\
\hline 115 & St-S-Ss-H-Sw-Ss-Sw-S & PEg115 & & & 1 & & & & & & & 1 \\
\hline 116 & St-S-Ss-H-Sw-Ss-H-Sw & PEg116 & & 1 & & & & & & & & 1 \\
\hline 117 & St-S-Ss-H-Di-Sw & PEg117 & & & 1 & & & & & & & 1 \\
\hline 118 & St-S-TL-Sf & PEg118 & & & & & & & & 1 & & 1 \\
\hline 119 & St-S-TL-Ss-Sw & PEg119 & & & & & & & & 1 & & 1 \\
\hline 120 & St-S-Ia-Sf & PEg120 & & & & & 2 & & & & 1 & 3 \\
\hline 121 & St-S-Ia-Sf-Dr-Ia-Dr & PEg121 & & & & & & & & 1 & & 1 \\
\hline 122 & St-S-Ia-Ss-Sw & PEg122 & & & & & & & & & 1 & 1 \\
\hline 123 & St-S-P-S-Dr-S-Ss-H-Sw & PEg123 & & & & & 1 & & & & & 1 \\
\hline 124 & St-Dr-Sf & PEg124 & & & & & & & 1 & & & 1 \\
\hline 125 & St-Dr-Sf-Sf-S & PEg125 & & & & & & 1 & & & & 1 \\
\hline 126 & St-Ia-Sf & PEg126 & & & & & & & & 1 & & 1 \\
\hline 127 & St-Ia-Sf-Ia & PEg127 & & & & & & & & 3 & & 3 \\
\hline 128 & St-Ia-Sf-Ia-Sf-Ia-Sf-Ia-Sf & PEg128 & & & & & & & & 1 & & 1 \\
\hline 129 & $\begin{array}{l}\text { St-Ia-Sf-Ia-Sf(5)-Ia-Ss-Sw-Sf-Sf- } \\
\text { Ia }\end{array}$ & PEg129 & & & & & & & & 1 & & 1 \\
\hline 130 & St-P-Ss-Sw-Ss-Sw-Ia-I & PEg130 & & & & & & & & 1 & & 1 \\
\hline
\end{tabular}


Tabel lampiran 2. Pola mencari makan yang dilakukan Egrettagarzetta (lanjutan)

\begin{tabular}{|c|c|c|c|c|c|c|c|c|c|c|c|c|}
\hline NO & POLA MAKAN & Kode & 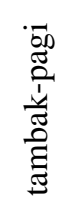 & 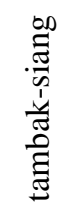 & 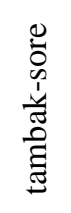 & 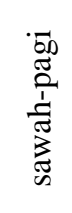 & 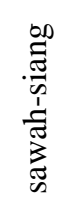 & 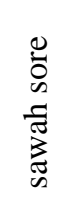 & $\begin{array}{l}\overline{00} \\
\widetilde{0} \\
\stackrel{1}{\Xi} \\
\Xi \\
\Xi \\
\Xi\end{array}$ & 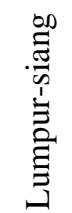 & 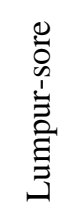 & 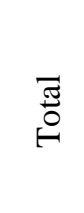 \\
\hline 131 & St-TL-S-Sf & PEg131 & & & & & 1 & & & & & 1 \\
\hline 132 & Fs-Sf & PEg132 & & & 1 & & & & & & & 1 \\
\hline 133 & Fs-Sf-S & PEg133 & 97 & 6 & 20 & 12 & 4 & 11 & 7 & 7 & 43 & 207 \\
\hline 134 & Fs-Sf-Ia & PEg134 & 2 & & & & & & & 1 & & 3 \\
\hline 135 & Fs-Sf-Ss-Sw & PEg135 & & & & & & & & & 1 & 1 \\
\hline 136 & Fs-Sf-Ss-Sw-Ss-Sw & PEg136 & 9 & & & & 1 & & 1 & & 1 & 12 \\
\hline 137 & Fs-Sf-Ss-Sw-Sf-Sf-Ss-Sw & PEg137 & & & & & & & & 2 & & 2 \\
\hline 138 & Fs-Sf-Sf & PEg138 & & & & & & & & 1 & & 1 \\
\hline 139 & Fs-Sf-Sf-S & PEg139 & 19 & & 1 & 1 & & 1 & 1 & 1 & 1 & 25 \\
\hline 140 & Fs-Sf-Sf-Ss-Sw & PEg140 & & & & 2 & & & & & & 2 \\
\hline 141 & Fs-Sf-Sf-Sf & PEg141 & 3 & & & & & 1 & & & 1 & 5 \\
\hline 142 & Fs-Sf-Sf-Sf-Ss-Sw & PEg142 & 1 & & & 1 & & & & & 2 & 4 \\
\hline 143 & Fs-Sf-Sf-Sf-Sf-Sf-Sf & PEg143 & 1 & & & & & & & & & 1 \\
\hline 144 & Fs-Ss-Sw & PEg144 & & & & & & & & & 1 & 1 \\
\hline 145 & Fs-Ss-Sw-S & PEg145 & 60 & 5 & 9 & 3 & 5 & 6 & 3 & 7 & 13 & 111 \\
\hline 146 & Fs-Ss-Sw-Sf & PEg146 & 1 & & & & & & & 1 & & 2 \\
\hline 147 & Fs-Ss-Sw-Ss-Sw & PEg147 & 1 & & & & & & & & & 1 \\
\hline 148 & Fs-Ss-Sw-Ss-Sw-Ss-Sw & PEg148 & 2 & & & & & 1 & & & & 3 \\
\hline 149 & Fs-Ss-Sw-Sf-Ss-Sw & PEg149 & 1 & & & & & & & & & 1 \\
\hline 150 & Fs-Ss-Sw-S-Dr & PEg150 & 1 & & & & & & & & & 1 \\
\hline 151 & Fs-Ss-Sw-S-Ss-Sw-S-Dr & PEg151 & 1 & & & & & & & & & 1 \\
\hline 152 & $\begin{array}{l}\text { Fs-Ss-Sw-S-Ss-Sw-Sf-Sf-S-Sf-Ss- } \\
\text { Sw-Sf }\end{array}$ & PEg152 & & & 1 & & & & & & & 1 \\
\hline 153 & Fs-Ss-H-Sw & PEg153 & & & & & & & & 1 & & 1 \\
\hline 154 & Fs-Ss-H-Sw-Dr & PEg154 & 1 & 1 & 3 & & & & & & & 5 \\
\hline 155 & Fs-Ss-H-Sw-S-Dr & PEg155 & 2 & & & & & & & & & 2 \\
\hline 156 & Fs-S-Sf & PEg156 & 1 & & & & & & & & & 1 \\
\hline 157 & Fs-S-Sf-S & PEg157 & 1 & & 2 & 14 & & & & & & 17 \\
\hline 158 & Fs-S-Ss-Sw & PEg158 & & & 1 & & & & & & & 1 \\
\hline 159 & Fs-S-Ss-Sw-Ia & PEg159 & & & & 3 & & & & & & 3 \\
\hline \multirow[t]{2}{*}{160} & Fs-S-Ss-Sw-Ss-H-Sw & PEg160 & & & & 1 & & & & & & 1 \\
\hline & T O T A L & & 375 & 247 & 376 & 279 & 184 & 188 & 237 & 264 & 241 & 2391 \\
\hline
\end{tabular}

Tabel Lampiran 3. Pola mencari makan yang dilakukan Bubulcus ibis

\begin{tabular}{|c|c|c|c|c|c|c|c|c|c|}
\hline No & POLA MAKAN & Kode & 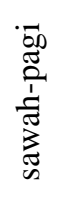 & 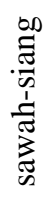 & 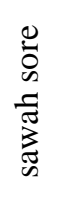 & 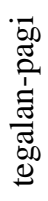 & 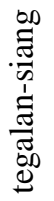 & 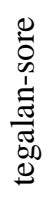 & 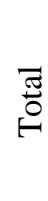 \\
\hline 1 & St-Sf & PBi1 & 18 & 8 & 30 & 2 & 3 & 1 & 62 \\
\hline 2 & St-Sf-S & $\mathrm{PBi} 2$ & 3 & 1 & 7 & 3 & & & 14 \\
\hline 3 & St-Sf-Ss-Sw & PBi3 & 2 & & 2 & & & & 4 \\
\hline 4 & St-Sf-Ss-Sw-S & $\mathrm{PBi} 4$ & 1 & & & & & & 1 \\
\hline
\end{tabular}




\begin{tabular}{|c|c|c|c|c|c|c|c|c|c|}
\hline No & POLA MAKAN & Kode & 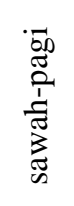 & 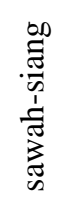 & 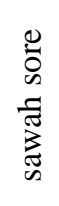 & 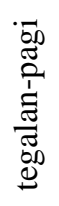 & 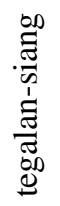 & 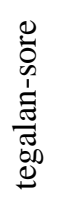 & $\stackrel{\bar{\Xi}}{0}$ \\
\hline 5 & St-Sf-Sf & $\mathrm{PBi} 5$ & 1 & 2 & 2 & 1 & & & 6 \\
\hline 6 & St-Sf-Sf-S & PBi6 & & & 1 & & & & 1 \\
\hline 7 & St-Sf-Sf-Ss-Sw & PBi7 & 2 & 1 & & & & & 3 \\
\hline 8 & St-Sf-Sf-S-Sf-S & PBi8 & & & & 1 & & & 1 \\
\hline 9 & St-Sf-Sf-Sf & PBi9 & 1 & & & & & & 1 \\
\hline 10 & St-Sf-Sf-Sf-Ss-Sw & PBi10 & 1 & & & 1 & & & 2 \\
\hline 11 & St-Sf-Sf-Sf-Ss-S-Sf-S & PBi11 & & & & 1 & & & 1 \\
\hline 12 & St-Sf(5)-S-Sf-S-Sf-S-Tl-S & PBi12 & & & & 1 & & & 1 \\
\hline 13 & St-Sf-Ia & PBi13 & & & & 1 & 3 & & 4 \\
\hline 14 & St-Sf-Ia-Sf-Ia & PBi14 & & & & & 1 & & 1 \\
\hline 15 & St-Ss-Sw & PBi15 & 100 & 21 & 42 & 24 & 9 & 4 & 200 \\
\hline 16 & St-Ss-Sw-Ia & PBi16 & & & 1 & & 12 & & 13 \\
\hline 17 & St-Ss-Sw-Dr & PBi17 & 1 & & 1 & & & & 2 \\
\hline 18 & St-Ss-Sw-S & PBi18 & 6 & & 5 & 7 & 3 & 1 & 22 \\
\hline 19 & St-Ss-Sw-S-Dr & PBi19 & & & 1 & & & & 1 \\
\hline 20 & St-Ss-Sw-Ss-Sw & PBi20 & 4 & & 4 & 1 & 1 & & 10 \\
\hline 21 & St-Ss-Sw-Ss-Sw-Ss-Sw & PBi21 & 1 & 1 & & & & & 2 \\
\hline 22 & St-Ss-Sw-Ss-Sw-Ia & PBi22 & & & 1 & & & & 1 \\
\hline 23 & St-Ss-Sw-Ss-H-Sw & PBi23 & & & & & & 1 & 1 \\
\hline 24 & St-Ss-Sw-S-Sf & PBi24 & 2 & & & & & & 2 \\
\hline 25 & St-Ss-Sw-S-Ss-Sw & PBi25 & 1 & & & 1 & & & 2 \\
\hline 26 & St-Ss-Sw-Sf-Sfs-Sw & PBi26 & 1 & & & & & & 1 \\
\hline 27 & St-Ss-Sw-Sf-Sf & PBi27 & 1 & & & & & & 1 \\
\hline 28 & St-Ss-Sw-Sf-Sf-Ss-H-E-Rh-H-Sw & PBi28 & & & & & 1 & & 1 \\
\hline 29 & St-Ss-S-Sf-S-Sf-S & PBi29 & & & & 1 & & & 1 \\
\hline 30 & St-Ss-H-Sw & PBi30 & 4 & 1 & 3 & 2 & & & 10 \\
\hline 31 & St-Ss-H-Sw-Ia & PBi31 & & & 1 & & & & 1 \\
\hline 32 & St-Ss-H-Sw-S & PBi32 & 2 & & 3 & 2 & & & 7 \\
\hline 33 & St-Ss-H-Sw-S-Dr & PBi33 & 1 & & & & & & 1 \\
\hline 34 & St-Ss-H-Sw-S-Ss-H-Sw-S & PBi34 & & & & 1 & & & 1 \\
\hline 35 & St-Ss-H-Sw-Ss-H-Sw & PBi35 & 1 & & & & & & 1 \\
\hline 36 & St-Ss-H-Sw-Ss-H-Sw-Ss-H-Sw & PBi36 & & & & 1 & 1 & & 2 \\
\hline 37 & St-Ss-H-Di-E-Rh-Sw & PBi37 & & & 1 & & & & 1 \\
\hline 38 & St-S-Sf & PBi38 & 6 & 1 & 6 & 5 & 4 & 2 & 24 \\
\hline 39 & St-S-Sf-S & PBi39 & & & 5 & 1 & & 1 & 7 \\
\hline 40 & St-S-Sf-S-Ss-Sw & PBi40 & & & 1 & & & & 1 \\
\hline 41 & St-S-Sf-S-Ss-H-E-Sf-Sf-S-Sf & PBi41 & 1 & & & & & & 1 \\
\hline 42 & St-S-Sf-Ia & PBi42 & 1 & & & 2 & 2 & & 5 \\
\hline 43 & St-S-Sf-Ia-Sh-Sf & PBi43 & 1 & & & & & & 1 \\
\hline 44 & St-S-Sf-Ia-Ss-Sw-Ia & PBi44 & & & & 1 & & & 1 \\
\hline 45 & St-S-Sf-Sf-Ia & PBi45 & & & & & 1 & & 1 \\
\hline 46 & St-S-Sf-Ss-Sw & PBi46 & & 1 & 1 & & & & 2 \\
\hline 47 & St-S-Sf-Ss-H-Sw-S & PBi47 & & & & 1 & & & 1 \\
\hline 48 & St-S-Sf-Sf-Ss-Sw-Ss-Sw & PBi48 & & & 1 & & & & 1 \\
\hline 49 & St-S-Sf-Sf-S & PBi49 & & & 1 & & & & 1 \\
\hline 50 & St-S-Sf-S-Sf-Ss-Sw-S-Ss-Sw & $\mathrm{PBi50}$ & & & 1 & & & & 1 \\
\hline 51 & St-S-Sh-Ss & PBi51 & & & & 1 & & & 1 \\
\hline
\end{tabular}




\begin{tabular}{|c|c|c|c|c|c|c|c|c|c|}
\hline No & POLA MAKAN & Kode & 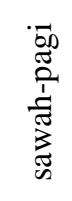 & 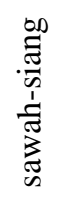 & 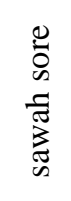 & 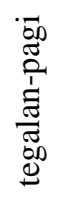 & 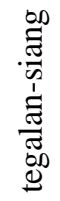 & 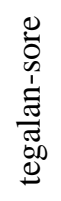 & $\begin{array}{l}\text { त्ञ } \\
\ominus\end{array}$ \\
\hline 52 & St-S-Ss-Sw & PBi52 & 5 & & 9 & 6 & 6 & 1 & 27 \\
\hline 53 & St-S-Ss-Sw-Ia & $\mathrm{PBi} 53$ & 3 & & & & 5 & & 8 \\
\hline 54 & St-S-Ss-Sw-P & PBi54 & 1 & & & & & & 1 \\
\hline 55 & St-S-Ss-Sw-S & $\mathrm{PBi} 55$ & 1 & & 2 & 7 & & & 10 \\
\hline 56 & St-S-Ss-Sw-Dr & PBi56 & & & 1 & & & & 1 \\
\hline 57 & St-S-Ss-Sw-Ss-Sw & $\mathrm{PBi} 57$ & & & 1 & 1 & & & 2 \\
\hline 58 & St-S-Ss-Sw-Ss-Sw-Dr & PBi58 & 1 & & & & & & 1 \\
\hline 59 & St-S-Ss-Sw-Ss-Sw-S-Ss-Sw & PBi59 & & & 1 & & & & 1 \\
\hline 60 & St-S-Ss-Sw-Sf-S & PBi60 & & & 1 & & & & 1 \\
\hline 61 & St-S-Ss-H-Sw & PBi61 & & & & & 2 & & 2 \\
\hline 62 & St-S-TL-Ss-Sw-S-Ss-H-Sw-S-TL-S & PBi62 & & & 1 & & & & 1 \\
\hline 63 & St-S-Dr-Ss-Sw & PBi63 & & & & 1 & & & 1 \\
\hline 64 & St-S-Ia-Ss-Sw & PBi64 & 1 & & & & & & 1 \\
\hline 65 & St-TL-Sf-Ss-Sw-Dr & PBi65 & 1 & & & & & & 1 \\
\hline & Tot a l & & 176 & 37 & 137 & 77 & 54 & 11 & 492 \\
\hline
\end{tabular}

